Чайка Т. О., кандидат економічних наук

Миколаївський національний аграрний університет

\title{
ЕКОЛОГІЧНІ НАСЛІДКИ ТРАДИЦІЙНОГО СІЛЬСЬКОГО ГОСПОДАРСТВА
}

\section{Рецензент - доктор сільськогосподарських наук П. В. Писаренко}

\begin{abstract}
Визначено необхідність формування нового розуміння світу на засадах моралі й етичних ідеалів добра і любові. Обтрунтовано необхідність розвитку аграрного сектора економіки на засадах соиіоекономіко-екологічної системи через визначення впливу негативних сторін традииійного сільськогосподарського виробництва на економіку, екологію та населення країн. Наведено наслідки використання ГМО та ГМ-культур у сільському господарстві, щуо обумовлює необхідність розвитку органічного агровиробництва на території Украӥни.
\end{abstract}

Ключові слова: традиційне сільськогосподарське виробництво, сільське господарство, генетично модифіковані організми, стійкий розвиток, соиіо-економіко-екологічна система, органічне агровиробництво.

Постановка проблеми. Переконливі успіхи науково-технічного прогресу (здебільшого матеріальні) зумовили становлення споживацького характеру цивілізації, внаслідок чого відбувалося атрофування засад моралі, що призвело до духовної кризи. Сучасна людина за своєю суттю $\epsilon$ прагматичною та цинічною, - до всього ставиться із сумнівом, у тім числі й до моралі як суспільної цінності. Отже, виникає потреба в етиці, орієнтованій на формування відчуття персональної та колективної відповідальності за стан біосфери перед сучасним i майбутніми поколіннями.

Сучасна етика бере на себе відповідальність за благо людей, у тому числі їніх майбутніх поколінь, а також за всі інші форми життя. Всупереч глобальним загрозам сучасності вона пропонує суттєві ціннісні переорієнтації свідомості в напрямі культивування поваги та любові, відмову від традиційних споживацьких установок до природи.

Аналіз основних досліджень і публікацій, у яких започатковано розв'язання проблеми. Сучасний рівень розвитку науково-технічного прогресу відкриває значні перспективи для розвитку всіх секторів економіки, а особливо - для аграрного, який є стратегічним для людства. Однак при цьому відбувається конфлікт інтересів «людина - природа» $[2,3]$, який не враховує за- конів глобальної екологічної системи [1, 6-10]. Це вже призводить до невиправних порушень в екосистемі [4], що загрожує існуванню людства взагалі. У зв'язку з цим виникає необхідність розвитку альтернативних систем виробництва, серед яких на сьогодні $\epsilon$ найбільш розповсюдженою органічна [5]. Отже, визначення екологічних проблем, що виникають через використання традиційних технологій у сільському господарстві, вимагає детального дослідження.

Мета досліджень - дослідити негативні наслідки ведення сільського господарства за традиційною технологією, що обумовлює необхідність переходу на альтернативні технології, наприклад, органічні.

Завдання досліджень - визначити негативні сторони ведення традиційного сільського господарства для економіки, екології та суспільства; обгрунтувати необхідність заборони використання генетично модифікованих організмів (ГМО) у сільському господарстві.

Матеріали і методи досліджень. У дослідженні використовувався метод узагальнення для визначення впливу традиційного сільського господарства та генетично модифікованих організмів.

Результати досліджень. Ставлення людини до природи нині набуває такого ж морального значення, як і ставлення людини до людини. За своєю сутністю - це одне й те саме ставлення, і цю обставину мають на увазі, коли ведуть мову про перехід морального імперативу в імператив екологічний [3]. Без сумніву, розвиватися до етичних ідеалів добра й любові - це необхідна передумова збереження й утвердження життя на Землі. Саме на цих засадах повинне формуватися нове розуміння світу, головним орієнтиром якого має стати усвідомлення того, що людина включена в єдину глобальну екологічну систему, вона живе не лише в соціальному, але й у природному контексті; розуміння того, що людство - не власник природи, а один із членів природного співтовариства, і в цьому відношенні не має привілеїв. У співіснуванні «природа - людина» необхідним є проголошення людської єдності 3 навколишнім середовищем і поваги до нього, 
надання природі статусу повноправного суб'єкта у взаємовідносинах із суспільством.

Сьогодні 3 позицій синтезу природничих i гуманітарних наук існує спроба вирішити цю проблему в теорії «sustainable development», яка перекладається українською мовою як стійкий (або сталий) розвиток і $є$ близьким до поняття «екорозвиток». Стійкий розвиток - це модель функціонування системи із обмеженими параметрами, що забезпечує збалансовану динамічну рівновагу протягом визначеного проміжку часу між компонентами інтегрованої соціо-економіко-екологічної системи [2]. Його мета полягає у пошуку парадигми об'єднання економічного зростання й підвищення життєвого рівня 3 поліпшенням стану навколишнього середовища. Теорія стійкого розвитку грунтується на альтернативних цінностях, методах, переконаннях, порівняно з економічним зростанням, яке ігнорує екологічну небезпеку від розвитку за екстенсивною та інтенсивною моделями.

Концепція стійкого розвитку суттєво залежить від раціонального, бережливого й поважного ставлення до природи. У зв'язку з цим набуває наразі актуальності розвиток органічного виробництва в аграрному секторі, який $\epsilon$ основною ланкою забезпечення життєдіяльності людини і передумовою результативної реалізації концепції сталого розвитку. Його виникнення пов'язано 3 появою органічного землеробства як протесту проти розвитку хімічної та технологічної інтенсифікації сільського господарства у країнах Центральної та Західної Європи, економіка яких знаходилася на фазі піднесення завдяки використанню здобутків науково-технічного прогресу (табл. 1).

\section{1. Негативні сторони традиційного сільського господарства *}

\begin{tabular}{|c|c|c|}
\hline Причина & $\begin{array}{c}\text { Практика традиційного } \\
\text { землеробства }\end{array}$ & Наслідки \\
\hline \multirow{12}{*}{\begin{tabular}{|} 
Викорис- \\
тання \\
агрохімі- \\
чних \\
засобів
\end{tabular}} & \multirow{4}{*}{$\begin{array}{c}\text { Застосування швидко- } \\
\text { розчинних мінераль- } \\
\text { них (промислових) } \\
\text { добрив }\end{array}$} & $\begin{array}{c}\text { Експлуатація невідновлюваних ресурсів та енергії в процесі } \\
\text { виробництва. }\end{array}$ \\
\hline & & $\begin{array}{c}\text { Аварії на фабриках, ситуації, що виникають після виникнення } \\
\text { природних катастроф або військових конфліктів, промислове } \\
\text { забруднення у процесі виробництва. }\end{array}$ \\
\hline & & Забруднення грунтових і поверхневих вод (евтофізація). \\
\hline & & $\begin{array}{c}\text { Зниження родючості грунту та життєздатності культурних } \\
\text { рослин. }\end{array}$ \\
\hline & \multirow{3}{*}{$\begin{array}{c}\text { Надмірне використан- } \\
\text { ня синтетичних пести- } \\
\text { цидів у сільському } \\
\text { господарстві }\end{array}$} & Виникнення стійкості у шкідників, хвороб і бур'янів. \\
\hline & & $\begin{array}{c}\text { Зниження біологічного різноманіття, забруднення компонентів } \\
\text { навколишнього середовища та підвищення нестабільності } \\
\text { екосистем. }\end{array}$ \\
\hline & & $\begin{array}{c}\text { Залишки пестицидів у продуктах, їх негативний вплив } \\
\text { на здоров'я людей і тварин. }\end{array}$ \\
\hline & \multirow{3}{*}{$\begin{array}{c}\text { Виробництво, розпо- } \\
\text { всюдження та застосу- } \\
\text { вання агрохімічних } \\
\text { засобів }\end{array}$} & Експлуатація невідновлюваних ресурсів. \\
\hline & & $\begin{array}{c}\text { Отруєння та можливість забруднення поверхневих і грунтових } \\
\text { вод. }\end{array}$ \\
\hline & & $\begin{array}{c}\text { Залежність фермерів від хімічних концернів (виробників, } \\
\text { дистриб’юторів). }\end{array}$ \\
\hline & $\begin{array}{c}\text { Зберігання агрохіміч- } \\
\text { них засобів і ліквідація } \\
\text { старих запасів } \\
\end{array}$ & $\begin{array}{c}\text { Старі запаси на складах і неконтрольоване використання } \\
\text { підроблених запасів. }\end{array}$ \\
\hline & Невизначені наслідки & $\begin{array}{c}\text { Нові матеріали тривалої дії - проблеми, що виникають із часом } \\
\text { (наприклад, інсектицид ДДТ), неврахування кумулятивного і си- } \\
\text { нергетичного ефектів за умови одночасного застосування різних } \\
\text { агрохімічнимх засобів. } \\
\end{array}$ \\
\hline \multirow[t]{2}{*}{$\begin{array}{c}\text { Утриман- } \\
\text { ня тварин } \\
\text { і птахів }\end{array}$} & \multirow[t]{2}{*}{$\begin{array}{l}\text { Утримання тварин і } \\
\text { птахів промисловим } \\
\text { шляхом }\end{array}$} & $\begin{array}{l}\text { Спричинення страждань тваринам і птахам, погані умови утри- } \\
\text { мання, транспортування, забою. Надлишкові операції, що здійс- } \\
\text { нюються над тваринами (купірування хвостів, виламування } \\
\text { зубів, укорочування дзьобів). Страждання тварин призводить до } \\
\text { погіршення якості продуктів тваринництва. Кліткове утримання }\end{array}$ \\
\hline & & $\begin{array}{c}\text { Забруднення навколишнього середовища відходами великих } \\
\text { відгодівельних пунктів і тваринницьких ферм. }\end{array}$ \\
\hline
\end{tabular}


Продовження табл. 1

\begin{tabular}{|c|c|c|}
\hline & $\begin{array}{c}\text { Застосування промис- } \\
\text { лових кормових сумі- } \\
\text { шей (стимулятори рос- } \\
\text { ту, синтетичні смакові } \\
\text { приправи та консерва- } \\
\text { нти, профілактичне } \\
\text { застосування лікарсь- } \\
\text { ких засобів (антибіоти- } \\
\text { ки, сповільнювачі), } \\
\text { кормів, виготовлених } \\
\text { із м’ясо-кісткового бо- } \\
\text { рошна (травоїдні тва- } \\
\text { рини), гормональних } \\
\text { засобів тощо }\end{array}$ & $\begin{array}{c}\text { Забруднення кормів матеріалами неземлеробського походження. } \\
\text { Залишки пестицидів у продуктах, зниження опірності організму, } \\
\text { міжнародні конфлікти («коров’ячий сказ», ПХБ, гормони та } \\
\text { діоксин у продуктах тощо). }\end{array}$ \\
\hline & $\begin{array}{c}\text { Керована репродукція, } \\
\text { штучне запліднення, } \\
\text { селекція видів, однобі- } \\
\text { чно направлена на ви- } \\
\text { соку продуктивність } \\
\end{array}$ & \begin{tabular}{|} 
Зниження тривалості життя тварин (наприклад, дійних корів), \\
зниження опірності до хвороб (збільшує витрати на ліки в межах \\
інтенсивних методів утримання). \\
Результатом гібридизації в межах селекції є вузько спеціалізовані, \\
нежиттєздатні у звичайних умовах лінії (наприклад, бройлери). \\
\end{tabular} \\
\hline $\begin{array}{c}\text { Зберіган- } \\
\text { ня та пе- } \\
\text { реробка } \\
\text { продукції }\end{array}$ & $\begin{array}{c}\text { Зменшення прямих } \\
\text { закупівель продуктів у } \\
\text { землеробів, збільшення } \\
\text { відстані перевезень, } \\
\text { потреба у продуктах із } \\
\text { тривалим терміном } \\
\text { зберігання }\end{array}$ & $\begin{array}{c}\text { Недостатня кількість свіжих продуктів харчування для спожива- } \\
\text { чів. Продаж одноманітних продуктів низької якості. } \\
\text { Традиційні продукти піддаються надмірній технологічній оброб- } \\
\text { ці (гомогенізація, наприклад, молоко; подрібнення структури - } \\
\text { екструзія, мікрохвильовий нагрів тощо). } \\
\text { Продукти містять шкідливі консерванти, смакові добавки тощо } \\
\text { (додаткові речовини - позначення «Е»). } \\
\text { Змінюється природний склад продуктів (мінеральних речовин, } \\
\text { амінокислот, вітамінів тощо та їх пропорції). }\end{array}$ \\
\hline \begin{tabular}{l|} 
Зміна \\
структури \\
сільського \\
господар- \\
ства та \\
економіч- \\
ного стану \\
фермерів \\
\end{tabular} & $\begin{array}{c}\text { Нова техніка, розвиток } \\
\text { селекції та } \\
\text { гібридизації. } \\
\text { Нові різноманітні } \\
\text { засоби від інших по- } \\
\text { стачальників }\end{array}$ & $\begin{array}{c}\text { Збільшується залежність від виробників і постачальників додат- } \\
\text { кових засобів (наприклад, від селекціонерів посівних матеріалів } \\
\text { - гідбридні та генномодифіковані посівні матеріали не можна } \\
\text { пересівати). } \\
\text { Фермерське господарство перестало бути самодостатньою за- } \\
\text { мкнутою системою і все більше залежить від зовнішніх структур. } \\
\text { Підвищення вартості зовнішніх структур. }\end{array}$ \\
\hline $\begin{array}{c}\text { Фермери } \\
\text { залежать } \\
\text { від еко- } \\
\text { номічної } \\
\text { ефектив- } \\
\text { ності }\end{array}$ & $\begin{array}{c}\text { Зниження } \\
\text { закупівельних цін }\end{array}$ & $\begin{array}{c}\text { Тиск на фермерів на користь спеціалізації (монокультури, збіль- } \\
\text { шення земельних площ) - пошкодження культурного ландшафту та } \\
\text { погіршення якості грунту. Тиск через постійне підвищення врожай- } \\
\text { ності культур і продуктивності тварин веде до надвиробництва. } \\
\text { Подальша інтенсифікація, концентрація та спеціалізація - } \\
\text { недолік фермерів на селі (розвиток країни: зниження чисельності } \\
\text { робітників у сільському господарстві з } 30 \text { \% до } 4 \text { \%). }\end{array}$ \\
\hline $\begin{array}{c}\text { Кінцеві } \\
\text { результа- } \\
\text { ти індуст- } \\
\text { ріалізації } \\
\text { сільського } \\
\text { господар- } \\
\text { ства } \\
\end{array}$ & \multicolumn{2}{|c|}{$\begin{array}{c}\text { Роль фермерів у суспільстві різко погіршилася (вони належать до групи з найнижчим } \\
\text { рівнем життя), погіршилась якість продукції, значна шкода нанесена ландшафту та } \\
\text { навколишньому середовищу. } \\
\text { Фермери постійно залежать від дотацій, стійкість культурних ландшафтів коштує суспі- } \\
\text { льству надто дорого. }\end{array}$} \\
\hline
\end{tabular}

Примітка: * - побудовано за [5] 


\section{2. Наслідки використання ГМО та ГМ-культур у сільському господарстві}

[Авторська розробка]

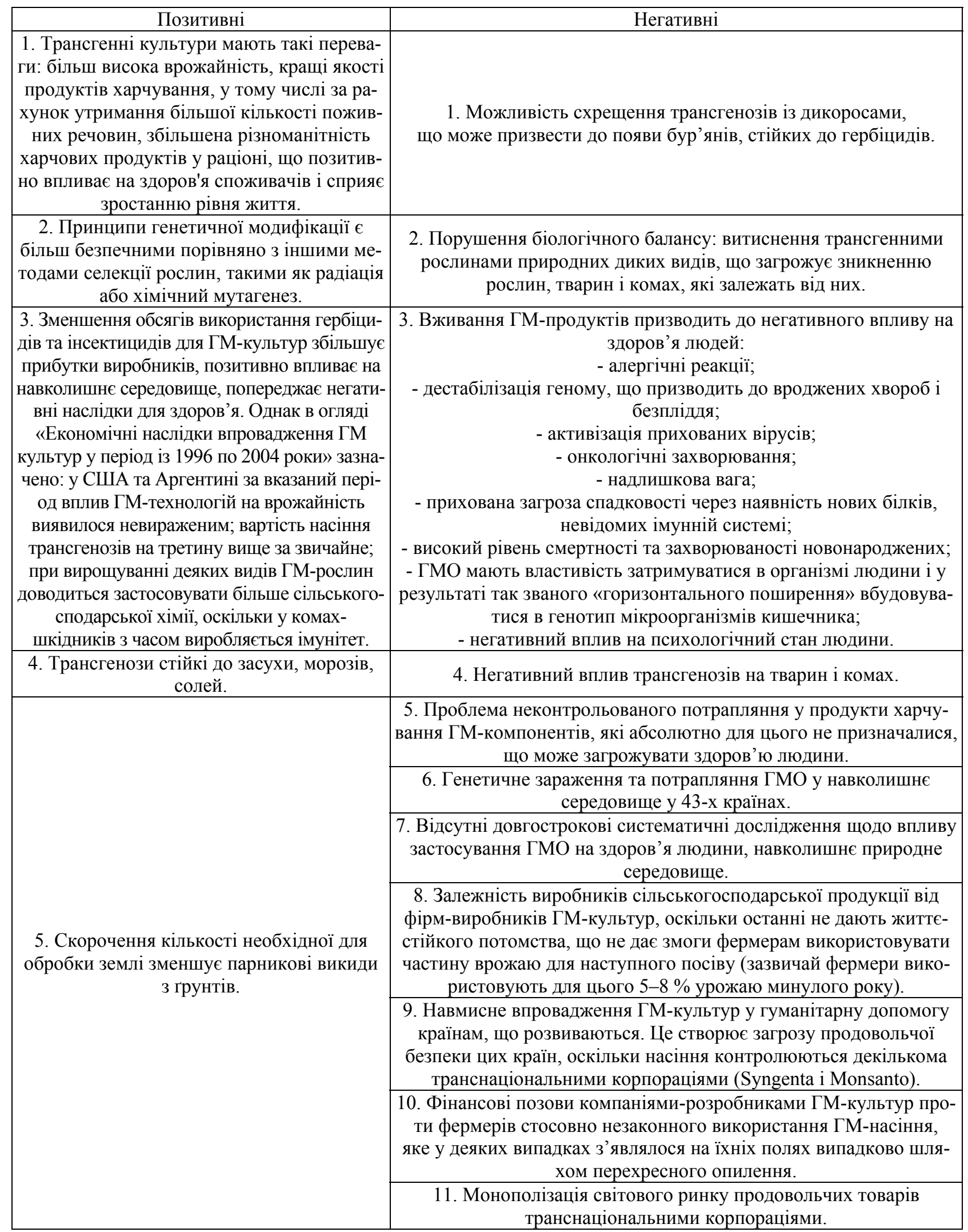


Таким чином, безпека споживання та необхідність збереження навколишнього природного середовища стають важливими факторами впливу на спосіб виробництва, розвиток його органічної складової. Нині у суспільстві відсутня єдина позиція щодо ГМО та ГМ-рослин (трансгенозів). Тому нами було проведено власне дослідження позитивних і негативних наслідків від їх використання у сільському господарстві (табл. 2) [4]. Так, 83,4 \% населення України негативно ставляться до ГМО, надаючи перевагу природним продуктам харчування. Також відповідно до даних телефонного опитування «Продукти 3 ГМО на нашому столі», яке проводилось Інститутом Горшеніна у листопаді 2009 р., 85,6 \% респондентів знають що таке ГМО, 93,4 \% вважають маркування продуктів 3 вмістом ГМО необхідним і 61,2 \% ніколи не будуть купувати таку продукцію [6].

Висновки: 1. Підсумовуючи вищевикладене, слід зауважити, що роль ГМО в порятунку населення світу від голоду дуже перебільшена. Такий підхід не враховує того, що справжня причина голоду в цих країнах полягає не у відсутності продуктів харчування та вітамінів, а в обмеженому доступі до них та у бідності населення. Так, наприклад, у 2002 р. в Індії було знищено 60 млн т зерна, тому що населення не мало коштів для його придбання, у Замбії в 2003 р. 3 тієї ж причини на складах згнило 300 тис. т маніоки [1, 9]. Рішення

\section{БІБЛІОГРАФІЯ}

1. ГМО: Контроль над обществом или общественный контроль / [В. Б. Копейкина, А. Л. Кочинева, О. А. Разбаш, Т. Ю. Саксина] ; под ред. В. Б. Копейкиной. - М. : Эремурус, 2005. - 197 с.

2. Котикова I. O. Організаційно-економічні основи стійкого розвитку сільськогосподарського землекористування : автореф. дис. ... д-ра екон. наук : 08.00.03 «Економіка та управління національним господарством» / І. О. Котикова. - Миколаїв, 2011. $35 \mathrm{c}$.

3. Кисельов М. М. Біологічна етика в системі практичної філософії / М. М. Кисельов // Практична філософія. - 2000. - № 1. - С. 166-174.

4. Чайка T. А. Генетически модифицированные организмы в сельском хозяйстве: перспективы и угрозы / Т. А. Чайка // Научные исследования - основа модернизации сельскохозяйственного производства : материалы Междунар. науч.-практ. конф., 9 нояб. 2011 г. - Тюмень, Россия, 2011. - С. 143-147.

5. Шарапатка Б. Органическое сельское хозяйство / Б. Шарапатка, И. Урбан. - Оломоуц, 2010. - 406 с. 6. Украинцы против ввоза в страну продуктов, содержащих ГМО - опрос [Електронний ресурс]. - проблеми та гарантія безпеки продуктів харчування полягає у подоланні соціальних і економічних бар'єрів, які обмежують купівельну спроможність бідних людей щодо продуктів харчування. Дорогі технології, такі як генна інженерія, що належать великим корпораціям, тільки збільшують ці бар'єри, приводячи малозабезпечені сім'ї до ще більшої бідності.

2. Вперше світове співтовариство всерйоз замислилося над доцільністю використання ГМО у 2000 році. Вчені заговорили про можливий негативний вплив трансгенних продуктів на здоров'я людини. Більше того, під сумнів була поставлена економічна вигода від їх застосування. У 2000 р. була опублікована «Світова заява вчених» [10], у якій ішлося про небезпеку генної інженерії, а згодом - «Відкритий лист вчених» [8] урядам усіх країн щодо безпеки та доцільності використання ГМО, підписаний 828 фахівцями 384 країн. У 2008 році за результатами трирічної роботи близько 400 вчених, урядів, представників громадянського суспільства і приватного сектора $\mathrm{OOH}$ подали доповідь, у якій повідомлялося, що ГМО не допоможуть врятувати світ від голоду і сільськгосподарської кризи [7]. На думку експертів, необхідно надавати більше уваги традиційній селекції та екологічно чистому сільськогосподарському виробництву.

Режим доступу : http://institute.gorshenin.ua /news/281_Ukraintsi_protiv_vvoza_v_stranu_p.html 7. International Assessment of Agricultural Knowledge, Science and Technology for Development (IAASTD): Synthesis Report with execute summary: A Synthesis of the Global and Sub-Global IAASTD Reports / Ed. by B. D. McIntyre (AASTD Secretariat), H. R. Herren (Millennium Institute), J. Wakhungu (African Centre for Technology Studies), R. T. Watson (University of East Anglia). Island Press, 2008. - 97 p.

8. Open Letter from World Scientists to All Governments Concerning Genetically Modified Organisms (GMOs) [Електронний ресурс]. - Режим доступу : http://www.i-sis.org.uk/list.php/

9. Voices from the South. CA: Institute for Food and Development // Pesticide Action Network, 2003 [Електронний pecypc]. - Режим доступу : http://www.foodfirst.org/.

10. World Scientists Statement. Supplementary Information of the Hazards of Genetic Engineering Biotechnology. Third World Network, 2000 [Електронний pecypc]. - Режим доступу : http://www.twnside. org.sg/title/worldsp-cn.htm. 